\title{
STUDIES ON BACTERIAL CELL WALL INHIBITORS* \\ VI. SCREENING METHOD FOR THE SPECIFIC INHIBITORS OF PEPTIDOGLYCAN SYNTHESIS
}

\author{
Satoshi Ōmura, Haruo Tanaka, Ruiko ÖIwa, Toshiaki Nagai**, \\ YASUAKI KOYAMA*** and YōKO TAKAHASHI \\ Kitasato University and The Kitasato Institute, Minato-ku, Tokyo, Japan
}

(Received for publication June 1, 1979)

\begin{abstract}
A screening method was established for selecting new specific inhibitors of bacterial cell wall peptidoglycan synthesis. In the primary test, culture broths of soil isolates were selected based on relative microbial activity. A culture, to be retained, must be active against Bacillus subtilis and lack activities against Acholeplasma laidlawii. In the secondary test, inhibitors of bacterial cell wall synthesis were identified by their ability to prevent the incorporation of meso$\left[{ }^{3} \mathrm{H}\right]$ diaminopimelic acid but not to prevent the incorporation of $\mathrm{L}-\left[{ }^{14} \mathrm{C}\right]$ leucine into the acidinsoluble macromolecular fraction of growing cells of Bacillus sp. ATCC 21206 (Dpm-). As the tertiary test, inhibitors with molecular weights under 1,000 were selected by passage through a Diaflo UM-2 membrane. By this screening procedure, six known antibiotics and one new one were picked out from ten thousand soil isolates.
\end{abstract}

A large number of antibiotics have been discovered in the past four decades, and many infectious diseases have been conquered by using antibiotics as chemotherapeutics. Additional useful antibiotics, however, are needed for the treatment of disease caused by drug-resistant microbes, of super infections, and of opportunistic infections. Unfortunately finding a new antibiotic has become more and more difficult.

Among the various types of known antibiotics, specific inhibitors of cell wall peptidoglycan synthesis are characterized in general by their lower toxicities. Consequently we attempted to establish a new screening method for such an inhibitor. The method described in this paper is based on the inactivity of cell wall inhibitors against $M y$ coplasma ${ }^{1)}$, which lack a cell wall ${ }^{2,3)}$, and on the inhibition of incorporation of meso-diaminopimelic acid (Dpm) into the acid-insoluble macromolecular fraction of Bacillus. Dpm is an amino acid present only in the peptidoglycan of Dpm-containing bacteria such as the bacilli. In the primary test, culture broths of soil isolates with activity against Bacillus but lacking activity against Mycoplasma were selected. The selected culture broths were further examined in the secondary test by determining their effect on incorporation of $\left[{ }^{3} \mathrm{H}\right] \mathrm{Dpm}$ and $\left[{ }^{14} \mathrm{C}\right]$ leucine into the acid-insoluble macromolecular fraction of a Dpm-requiring strains of Bacillus sp. Those culture broths which inhibited the incorporation of $\left[{ }^{3} \mathrm{H}\right] \mathrm{Dpm}$ but did not influence that of $\left[{ }^{14} \mathrm{C}\right]$ leucine were saved for further study.

In this paper we present the new method with evidence for its applicability.

* Part V. of this series appears in J. Biochem. 86: 155 159, 1979

** Present address: The Medical Department of Teikyo University, Itabashi-ku, Tokyo, Japan

*** Present address: Squibb Japan Inc., Toda, Saitama, Japan 


\section{Materials and Methods}

Mycoplasmal and bacterial strains

Mycoplasma gallisepticum KP-13 and Acholeplasma laidlawii PG 8 were obtained from Dr. C. KuniYasu, National Institute of Animal Health, Japan, and Dr. M. YoshiokA, Tokyo Women's Medical College, Japan. Bacillus sp. ATCC 21206 (Dpm-requiring strain) was obtained from Tokyo Res. Labs., Kyōwa Hakkō Kögyō Co., Ltd. B. subtilis PCI 219 and Escherichia coli NIHJ maintained in our laboratory were also used.

Preparation of seed or stock culture of M. gallisepticum and A. laidlawii

Eiken's avian PPLO medium was used for growth of $M$. gallisepticum. The PPLO medium (17.3 g) and phenol red $(10 \mathrm{mg})$ were dissolved into water (1 liter) and then sterilized for 15 minutes at $120^{\circ} \mathrm{C}$. To $100 \mathrm{ml}$ of the medium, $20 \mathrm{ml}$ of sterilized horse serum and 10,000 units of penicillin $\mathrm{G}$ were added and mixed. Each $8 \mathrm{ml}$ of the medium was transferred into a sterilized test tube, inoculated with $2 \mathrm{ml}$ of stock culture of the organism, and then incubated at $37^{\circ} \mathrm{C}$ for 24 hours. The culture was stored at $-70^{\circ} \mathrm{C}$. Phenol red was added to the medium as an indicator of growth of Mycoplasma, and penicillin was used to prevent contamination by bacteria. Seed and stock cultures of $A$. laidlawii were prepared with Hokken's PPLO medium by a method similar to that used for M. gallisepticum. Though it is known that Acholeplasma does not require sterols for growth ${ }^{4}$, better growth of this strain of Acholeplasma was observed with serum ( $20 \%$ in medium) than without it.

Assay method of antimicrobial activities

Antimycoplasmal and antibacterial activities were assayed by the paper disc method. Eiken's avian PPLO medium $(17.3 \mathrm{~g})$, phenol red $(10 \mathrm{mg})$ and agar $(12 \mathrm{~g})$ were dissolved into water (1 liter) and sterilized at $120^{\circ} \mathrm{C}$ for 15 minutes. The medium $(6 \mathrm{ml})$, sterilized horse serum $(2 \mathrm{ml})$ containing penicillin $\mathrm{G}(10,000$ units), and the seed culture of $M$. gallisepticum $(2 \mathrm{ml})$ were mixed and poured into a sterilized Petri dish $(9 \mathrm{~cm}$ in diameter) to prepare an agar plate. Inhibitory zones could be observed by 24 hours' incubation. Agar plates of A. laidlawii in Hokken's PPLO medium were prepared by a similar procedure. Agar plates of bacteria were prepared by the conventional method using a medium ( $\mathrm{pH} 7)$ containing peptone $(0.5 \%)$, meat extract $(0.5 \%)$ and agar $(1.0 \%)$.

Incorporation of $\left[{ }^{3} \mathrm{H}\right] \mathrm{Dpm}$ and $\left[{ }^{14} \mathrm{C}\right]$ leucine into acid-insoluble macromolecular fraction by growing cells of bacteria

Cells of a fresh slant culture of B. subtilis PCI 219 or Bacillus sp. ATCC 21206 (Dpm-) incubated overnight at $37^{\circ} \mathrm{C}$ were suspended in $5 \mathrm{ml}$ of a medium $(0.5 \%$ peptone, $0.5 \%$ meat extract, $200 \mu \mathrm{g} / \mathrm{ml}$ L-lysine, $10 \mu \mathrm{g} / \mathrm{ml} \mathrm{Dpm,} \mathrm{pH} 7.0$ ). The cell suspension was transferred into $10 \mathrm{ml}$ of the medium in a Monod tube to give an absorbance of 0.05 at $660 \mathrm{~nm}$, and then incubated at $37^{\circ} \mathrm{C}$ until the absorbance reached 0.2. A solution $(0.1 \mathrm{ml})$ containing meso- $\left[{ }^{3} \mathrm{H}\right] \mathrm{Dpm}(0.1 \mu \mathrm{Ci})$ and $\mathrm{L}-\left[{ }^{14} \mathrm{C}\right]$ leucine $(0.5 \mu \mathrm{Ci})$ and $0.1 \mathrm{ml}$ of the sample solution were added to $0.8 \mathrm{ml}$ of the culture and incubated for 10 minutes at $37^{\circ} \mathrm{C}$ with aeration. Growth was stopped by adding $5 \%$ trichloroacetic acid (TCA) into the culture. The acid-insoluble fraction was collected on a membrane filter (pore size, $0.22 \mu$ ) and washed twice with $5 \%$ TCA. The radioactivity of the acid-insoluble fraction on the filter was counted with a liquid scintillation counter using toluene scintillation fluid (4 g of 2,5-diphenyloxazole and $100 \mathrm{mg}$ of 1,4-bis[2-(5-phenyloxazolyl)]benzene in 1 liter of toluene).

Measurement of passing ratio through Diaflo UM-2 membrane

After discarding about $0.5 \mathrm{ml}$ of the initial filtrate through a Diaflo UM-2 membrane, the next fraction $(1 \sim 2 \mathrm{ml})$ was collected for assay by paper disc method using B. subtilis as test organism.

Antibiotics

Antibiotics were generous gifts from the following: actinomycin, novobiocin and streptonigrin from Chas Pfizer \& Co., Inc., N. Y., A-16886 A and vancomycin from Lilly Research Laboratories, Indiana, hedamycin from Bristol Laboratories, N. Y., lividomycin from Kōwa Co., Ltd., Tokyo, macarbomycin from Institute of Microbial Chemistry, Tokyo, polyoxin from Kaken Chemical Co., Ltd., Tokyo, and viomycin from Sankyo Co. Ltd., Tokyo. Bacillin, cerulenin, iyomycin, kinamycin, 
leucomycin and mitomycin were isolated in our laboratory. Others were stock materials of our laboratory or obtained commercially.

Radiochemicals

L-[U- $\left.{ }^{14} \mathrm{C}\right]$ Leucine $(330 \mathrm{mCi} / \mathrm{mmol})$ and $2,6-\left[\mathrm{G}-{ }^{3} \mathrm{H}\right]$ diaminopimelic acid $(300 \mathrm{mCi} / \mathrm{mmol})$ were obtained from the Radiochemical Center, Amersham, U. K.

\section{Results and Discussion}

\section{Antimycoplasmal Activity of Antibiotics}

Antimycoplasmal and antibacterial activities of various antibiotics were compared to determine whether comparative activity can be useful as the primary test for screening for specific inhibitors of the synthesis of bacterial cell wall peptidoglycan. As shown in Table 1, inhibitors of protein biosynthesis or nucleic acid synthesis, such as tetracyclines, macrolides, actinomycin $\mathrm{D}$, iyomycin, dauno-

Table 1. Antimicrobial activities of various antibiotics against M. gallisepticum, A. laidlawii, B. subtilis and E. coli.

\begin{tabular}{|c|c|c|c|c|c|}
\hline \multirow{2}{*}{$\begin{array}{l}\text { Antibiotic } \\
(100 \mu \mathrm{g} / \mathrm{ml})\end{array}$} & \multirow{2}{*}{$\begin{array}{l}\text { Mode of } \\
\text { action* }\end{array}$} & \multicolumn{4}{|c|}{ Antimicrobial activity* } \\
\hline & & M. gal. & A. lai. & B. sub. & E. colt \\
\hline Tetracycline & $\mathrm{P}$ & + & $++t$ & + & + \\
\hline Oxytetracycline & $\mathrm{P}$ & ++ & $+t$ & + & - \\
\hline Leucomycin & $\mathrm{P}$ & ++ & ++ & + & \pm \\
\hline Amaromycin & $\mathrm{P}$ & ++ & + & + & - \\
\hline Streptomycin & $\mathrm{P}$ & - & $+t$ & + & ++ \\
\hline Dihydrostreptomycin & $\mathrm{P}$ & - & ++ & ++ & + \\
\hline Kanamycin & $\mathrm{P}$ & - & + & + & $+t$ \\
\hline Kanamycin B & $\mathrm{P}$ & - & + & + & ++ \\
\hline Lividomycin & $\mathrm{P}$ & - & - & + & + \\
\hline Bluensomycin & $\mathrm{P}$ & - & + & + & + \\
\hline Viomycin & $\mathrm{P}$ & - & - & + & + \\
\hline Colistin & M & - & - & - & + \\
\hline Actinomycin D & $\mathrm{N}$ & +++ & $+t+$ & ++ & - \\
\hline Iyomycin & $\mathrm{N}$ & + & + & + & - \\
\hline Daunomycin & $\mathrm{N}$ & + & + & + & \\
\hline Streptonigrin & $\mathrm{N}$ & + & $+t$ & + & $+t+$ \\
\hline Mitomycin C & $\mathrm{N}$ & ++ & $++t$ & ++ & $+t+$ \\
\hline Hedamycin & $\mathrm{N}$ & ++ & + & + & t. \\
\hline Kinamycin D & & + & + & + & + \\
\hline Cerulenin & $\mathrm{L}$ & + & - & ++ & $+t$ \\
\hline Azalomycin F & & - & + & + & - \\
\hline Xanthomycin & & + & + & + & - \\
\hline Penicillin G & W & - & - & + & - \\
\hline D-Cycloserine & W & - & - & + & - \\
\hline Vancomycin & W & - & - & + & - \\
\hline Ristocetin & W & - & - & + & - \\
\hline Cephaloridine & W & - & - & ++ & + \\
\hline
\end{tabular}

* P: Inhibition of protein synthesis

$\mathrm{N}$ : Inhibition of nucleic acid synthesis

M: Interference with cytoplasmic membrane

L: Inhibition of lipid synthesis

W: Inhibition of cell wall synthesis

** - : negative, $+: 10 \sim 20 \mathrm{~mm},++: 20 \sim 30 \mathrm{~mm},+++: 30 \sim 40 \mathrm{~mm}$ of diameter of inhibitory zone. 
mycin, streptonigrin, mitomycin $\mathrm{C}$ and hedamycin, were active against both mycoplasmas and bacteria. Penicillin G, D-cycloserine, vancomycin, ristocetin and cephaloridine, all inhibitors of bacterial cell wall synthesis, were active against $B$. subtilis but did not affect the growth of both Mycoplasma and Acholeplasma. M. gallisepticum KP-13 was not sensitive to aminoglycoside antibiotics $(100 \mu \mathrm{g} / \mathrm{ml})$ such as streptomycin, kanamycin and so on, but these antibiotics that are inhibitors of protein synthesis were active against $A$. laidlawii PG 8 . Some antibiotics such as lividomycin, viomycin and colistin were found to be inactive against the mycoplasmas at the concentrations tested.

From these results, it was ascertained that cell wall inhibitors could be selected in the primary screen by picking out antibacterial substances that were inactive against mycoplasmas. Antibiotics other than the cell wall inhibitors, which were inactive against mycoplasmas, could be eliminated by the following procedure.

\section{Influence of Antibiotics on Incorporation of $\left[{ }^{3} \mathrm{H}\right] \mathrm{Dpm}$ and $\left[{ }^{14} \mathrm{C}\right]$ Leucine into Acid-insoluble Fraction of Bacterial Cells}

In order to eliminate antibiotics that are not inhibitors of cell wall synthesis, effects of these antibiotics on incorporation of precursors of macromolecules biosynthesis were examined. B. subtilis PCI 219 and Bacillus sp. ATCC 21206 (Dpm-), containing meso-Dpm in peptidoglycan of cell wall, were used as test organisms and meso-Dpm and L-leucine were used as precursors of macromolecules. As shown in Table 2, incorporation of $\left[{ }^{3} \mathrm{H}\right] \mathrm{Dpm}$ into the acid-insoluble fraction of B. subtilis PCI 219 was about one-tenth of that in Bacillus sp. ATCC $21206\left(\mathrm{Dpm}^{-}\right)$. This difference can be explained by the fact that Dpm normally permeates through bacterial cell membrane with difficulty. So, the latter strain with the better incorporation was selected as the test organism. Next the medium and cultural conditions for Bacillus sp. ATCC $21206\left(\mathrm{Dpm}^{-}\right)$were standardized, as described in "Materials and Methods", so that adequate incorporation of the isotopes might be observed. L-Lysine was added to the medium to prevent the formation of labeled L-lysine from $\left[{ }^{3} \mathrm{H}\right] \mathrm{Dpm}$. In the selected experimental method, incorporation of both Dpm and leucine into Bacillus sp. ATCC 21206 (Dpm-) was observed to be adequate, as shown in Table 2. It was also observed that penicillin $\mathrm{G}$ prevented only the incorporation of $\left[{ }^{3} \mathrm{H}\right] \mathrm{Dpm}$ while chloramphenicol only prevented that of $\left[{ }^{14} \mathrm{C}\right]$ leucine.

Table 2. Effects of penicillin $\mathrm{G}$ and chloramphenicol on incorporation of $\left[{ }^{3} \mathrm{H}\right] \mathrm{Dpm}$ and $\left[{ }^{14} \mathrm{C}\right]$ leucine into the acid-insoluble fraction in B. subtilis PCI 219 or Bacillus sp. ATCC 21206 (Dpm-)

\begin{tabular}{|c|c|c|c|c|}
\hline & \multirow{2}{*}{ Antibiotic } & \multirow{2}{*}{$\begin{array}{c}\text { Concentration } \\
\mu \mathrm{g} / \mathrm{ml}\end{array}$} & \multicolumn{2}{|c|}{ Incorporation, cpm $(\%)$} \\
\hline & & & {$\left[{ }^{3} \mathrm{H}\right] \mathrm{Dpm}$} & {$\left[{ }^{14} \mathrm{C}\right]$ Leucine } \\
\hline \multirow{5}{*}{$\begin{array}{l}\text { Bacillus subtilis } \\
\text { PCI } 219\end{array}$} & - & - & $212(100)$ & $2,684(100)$ \\
\hline & Penicillin G & 10 & $222(105)$ & $2,930(109)$ \\
\hline & " & 100 & $173(82)$ & $2,851(106)$ \\
\hline & Chloramphenicol & 10 & $257(122)$ & 744 ( 28) \\
\hline & " & 100 & $174(82)$ & $199(7)$ \\
\hline \multirow{5}{*}{$\begin{array}{l}\text { Bacillus sp. ATCC } \\
21206\left(\mathrm{Dpm}^{-}\right)\end{array}$} & - & - & $1,873(100)$ & $2,074(100)$ \\
\hline & Penicillin G & 10 & $678(36)$ & $2,133(103)$ \\
\hline & $"$ & 100 & $605(32)$ & $2,153(104)$ \\
\hline & Chloramphenicol & 10 & $1,706(91)$ & $596(29)$ \\
\hline & $"$ & 100 & $1,717(92)$ & $264(13)$ \\
\hline
\end{tabular}


In order to examine whether the method is useful for differentiating inhibitors of cell wall synthesis from inhibitors of other metabolic function, known antibiotics of various modes of action were tested at various concentrations. As shown in Table 3, incorporation of $\left[{ }^{3} \mathrm{H}\right] \mathrm{Dpm}$ was inhibited while that of $\left[{ }^{14} \mathrm{C}\right]$ leucine was not prevented by inhibitors of cell wall synthesis. The inhibition of incorporation of $\left[{ }^{3} \mathrm{H}\right] \mathrm{Dpm}$ by moenomycin or macarbomycin was limited, suggesting low sensitivity of the organism to an antibiotic of moenomycin group. The inhibition of incorporation of $\left[{ }^{3} \mathrm{H}\right] \mathrm{Dpm}$ by a $\beta$-lactam antibiotic, such as penicillin $\mathrm{G}$, cephaloridine or A-16886 A, seems also to be limited. The incorporation ratios did not decrease under $30 \%$ even by $100 \mu \mathrm{g} / \mathrm{ml}$ of these antibiotics. This may be explained by the site of action of these antibiotics; they inhibit cross-linking reaction of nascent peptidoglycan chain, but do not inhibit formation of single chain of peptidoglycan. As shown in Table 4, protein synthesis inhibitors such as kanamycin and gentamicin did not affect the incorporation of $\left[{ }^{3} \mathrm{H}\right]$ Dpm, while streptomycin, leucomycin and tetracycline prevented it somewhat. In contrast, incorporation of $\left[{ }^{14} \mathrm{C}\right]$ leucine was inhibited more strongly than that of $\left[{ }^{3} \mathrm{H}\right] \mathrm{Dpm}$. Colistin and polymyxin $\mathrm{B}$, which interfere with the cytoplasmic membrane of bacterial cells, inhibited the incorporation of both $\left[{ }^{3} \mathrm{H}\right] \mathrm{Dpm}$ and $\left[{ }^{14} \mathrm{C}\right]$ leucine possibly resulting from disruption of the bacterial cells. Inhibitors of DNA

Table 3. Influence of cell wall synthesis inhibitors on the incorporation of $\left[{ }^{3} \mathrm{H}\right] \mathrm{Dpm}$ and $\left[{ }^{14} \mathrm{C}\right]$ leucine into acid-insoluble fraction in Bacillus sp. ATCC $21206\left(\mathrm{Dpm}^{-}\right)$.

\begin{tabular}{|c|c|c|c|}
\hline \multirow{2}{*}{ Antibiotic } & \multirow{2}{*}{$\begin{array}{c}\text { Concen- } \\
\text { tration } \\
(\mu \mathrm{g} / \mathrm{ml})\end{array}$} & \multicolumn{2}{|c|}{ Incorporation $(\%)$} \\
\hline & & {$\left[{ }^{3} \mathrm{H}\right] \mathrm{Dpm}$} & $\begin{array}{c}{\left[{ }^{14} \mathrm{C}\right]} \\
\text { Leucine }\end{array}$ \\
\hline $\begin{array}{l}\text { Bacillin } \\
\text { (Tetaine) }\end{array}$ & $\begin{array}{r}5 \\
50 \\
500\end{array}$ & $\begin{array}{r}45 \\
10 \\
9\end{array}$ & $\begin{array}{r}103 \\
119 \\
99\end{array}$ \\
\hline D-Cycloserine & $\begin{array}{r}2 \\
20 \\
200\end{array}$ & $\begin{array}{r}97 \\
32 \\
9\end{array}$ & $\begin{array}{l}100 \\
103 \\
102\end{array}$ \\
\hline Enduracidin & $\begin{array}{c}0.1 \\
1 \\
10 \\
100\end{array}$ & $\begin{array}{r}35 \\
9 \\
9 \\
0\end{array}$ & $\begin{array}{r}99 \\
96 \\
93 \\
9\end{array}$ \\
\hline Ristocetin & $\begin{array}{r}10 \\
100\end{array}$ & $\begin{array}{l}8 \\
8\end{array}$ & $\begin{array}{r}108 \\
90\end{array}$ \\
\hline Vancomycin & $\begin{array}{r}10 \\
100\end{array}$ & $\begin{array}{l}9 \\
4\end{array}$ & $\begin{array}{l}95 \\
98\end{array}$ \\
\hline Moenomycin & $\begin{array}{r}100 \\
1000\end{array}$ & $\begin{array}{l}98 \\
59\end{array}$ & $\begin{array}{l}105 \\
103\end{array}$ \\
\hline Macarbomycin & $\begin{array}{r}10 \\
100\end{array}$ & $\begin{array}{l}85 \\
52\end{array}$ & $\begin{array}{l}97 \\
98\end{array}$ \\
\hline Bacitracin & $\begin{array}{r}10 \\
100\end{array}$ & $\begin{array}{r}21 \\
7\end{array}$ & $\begin{array}{l}92 \\
95\end{array}$ \\
\hline Penicillin G & $\begin{array}{r}10 \\
100\end{array}$ & $\begin{array}{l}36 \\
32\end{array}$ & $\begin{array}{l}103 \\
104\end{array}$ \\
\hline Cephaloridine & $\begin{array}{r}10 \\
100\end{array}$ & $\begin{array}{l}44 \\
41\end{array}$ & $\begin{array}{l}101 \\
100\end{array}$ \\
\hline A-16886 A & $\begin{array}{r}10 \\
100\end{array}$ & $\begin{array}{l}74 \\
51\end{array}$ & $\begin{array}{r}103 \\
99\end{array}$ \\
\hline
\end{tabular}

Table 4. Influence of antibiotics other than cell wall synthesis inhibitors on the incorporation of $\left[{ }^{3} \mathrm{H}\right] \mathrm{Dpm}$ and $\left[{ }^{14} \mathrm{C}\right]$ leucine into the acid-insoluble fraction in Bacillus sp. ATCC 21206 (Dpm-)

\begin{tabular}{|c|c|c|c|}
\hline \multirow{2}{*}{ Antibiotic } & \multirow{2}{*}{$\begin{array}{c}\text { Concen- } \\
\text { tration } \\
(\mu \mathrm{g} / \mathrm{ml})\end{array}$} & \multicolumn{2}{|c|}{ Incorporation $(\%)$} \\
\hline & & {$\left[{ }^{3} \mathrm{H}\right] \mathrm{Dpm}$} & $\begin{array}{c}{\left[{ }^{14} \mathrm{C}\right]} \\
\text { Leucine }\end{array}$ \\
\hline Streptomycin & $\begin{array}{r}1 \\
10\end{array}$ & $\begin{array}{r}109 \\
70\end{array}$ & $\begin{array}{l}93 \\
25\end{array}$ \\
\hline Kanamycin & $\begin{array}{r}10 \\
100\end{array}$ & $\begin{array}{r}100 \\
99\end{array}$ & $\begin{array}{r}18 \\
7\end{array}$ \\
\hline Gentamicin & $\begin{array}{r}10 \\
100\end{array}$ & $\begin{array}{l}94 \\
83\end{array}$ & $\begin{array}{r}14 \\
5\end{array}$ \\
\hline Leucomycin & $\begin{array}{r}10 \\
100\end{array}$ & $\begin{array}{l}40 \\
37\end{array}$ & $\begin{array}{r}10 \\
4\end{array}$ \\
\hline Tetracycline & $\begin{array}{r}10 \\
100\end{array}$ & $\begin{array}{r}72 \\
2\end{array}$ & $\begin{array}{l}9 \\
7\end{array}$ \\
\hline Colistin & $\begin{array}{r}1 \\
10 \\
100\end{array}$ & $\begin{array}{r}93 \\
4 \\
1\end{array}$ & $\begin{array}{r}95 \\
20 \\
3\end{array}$ \\
\hline Polymyxin B & $\begin{array}{r}1 \\
10\end{array}$ & $\begin{array}{r}69 \\
5\end{array}$ & $\begin{array}{r}127 \\
31\end{array}$ \\
\hline Mitomycin C & $\begin{array}{r}1 \\
10\end{array}$ & $\begin{array}{l}110 \\
100\end{array}$ & $\begin{array}{r}105 \\
94\end{array}$ \\
\hline Novobiocin & $\begin{array}{r}1 \\
10 \\
100\end{array}$ & $\begin{array}{r}102 \\
100 \\
91\end{array}$ & $\begin{array}{r}105 \\
81 \\
70\end{array}$ \\
\hline Bleomycin & 100 & 109 & 111 \\
\hline Rifampicin & 100 & 91 & 45 \\
\hline Cerulenin & 100 & 71 & 49 \\
\hline
\end{tabular}


synthesis such as mitomycin $\mathrm{C}$, novobiocin and bleomycin did not affect the incorporation of both $\left[{ }^{3} \mathrm{H}\right] \mathrm{Dpm}$ and $\left[{ }^{14} \mathrm{C}\right]$ leucine, but rifampicin, an inhibitor of RNA synthesis, prevented that of $\left[{ }^{14} \mathrm{C}\right]$ leucine. This inhibition of protein synthesis may be a secondary effect caused by inhibition of RNA synthesis. Finally, cerulenin, an inhibitor of fatty acid synthesis, prevented incorporation of both $\left[{ }^{3} \mathrm{H}\right] \mathrm{Dpm}$ and $\left[{ }^{14} \mathrm{C}\right]$ leucine, with the latter more strongly affected than the former.

Generalizing from these results, incorporation of $\left[{ }^{3} \mathrm{H}\right] \mathrm{Dpm}$ was prevented by inhibitors of cell wall synthesis, cytoplasmic membrane, protein synthesis and fatty acid synthesis. The cell wall synthesis inhibitors were the only antibiotics that did not inhibit $\left[{ }^{14} \mathrm{C}\right]$ leucine incorporation even when the antibiotics were used in relatively high concentrations. Therefore, it seemed reasonable to eliminate antibiotics having a mode of action other than by inhibition of cell wall synthesis by this procedure.

Molecular Weights and Passing Ratios of Antibiotics through

\section{Diaflo UM-2 Membrane Filter}

Elimination of antibiotics of high molecular weight was attempted at an early stage of the screening system, because of their general lack of medical utility. Identification of antibiotics of molecular weight under 1,000 was tried with a membrane filter. As shown in Table 5, the passing ratio of colistin, molecular weight 967, through a Diaflo UM-2 membrane filter was 7.0\%. Vancomycin and ristocetin, with molecular weights of over 1,000 , also passed through the membrane by several per cent. Therefore, the criterion for eliminating an antibiotic having a molecular weight of greater than 1,000 was set about $7 \sim 8 \%$.

From the results mentioned above, the following procedure was established for screening specific inhibitors of cell wall peptidoglycan synthesis. In the primary test, culture broths were selected that showed activity against $B$. subtilis but lacked activity against $A$. laidlawii. In the secondary test, the broths were further selected by retaining those which inhibited only the incorporation of $\left[{ }^{3} \mathrm{H}\right] \mathrm{Dpm}$ into the acid-insoluble fraction of Bacillus sp. ATCC $21206\left(\mathrm{Dpm}^{-}\right)$. Finally antibiotics having molecular weights

Table 5. Passing ratios of various antibiotics through Diaflo UM-2 membrane filter.

\begin{tabular}{l|c|c}
\hline \multicolumn{1}{c|}{ Antibiotic } & $\begin{array}{c}\text { Molecular } \\
\text { weight }\end{array}$ & $\begin{array}{c}\text { Passing } \\
\text { ratio (\%) }\end{array}$ \\
\hline D-Cycloserine & 90 & 72.5 \\
Penicillin G & 356 & 22.0 \\
Cephalosporin C & 415 & 17.5 \\
Streptomycin & 581 & 32.0 \\
Colistin & 967 & 7.0 \\
Vancomycin & 1,600 & 5.4 \\
Ristocetin B & $>1,000$ & 6.0 \\
\hline
\end{tabular}
under 1,000 were retained.

\section{Results of this Screening Program}

Broth filtrates of about ten thousand strains including fungal, bacterial and actinomycete soil isolates were submitted to this screening program. One new antibiotic, azureomycin, and six known antibiotics, 3-amino-3-deoxy-D-glucose, amphomycin, D-cycloserine, penicillin G, ristocetin A and ristocetin $\mathrm{B}$, were identified in this program. Three antibiotics, amphomycin and ristocetins $\mathrm{A}$ and $\mathrm{B}$, had molecular weights over 1,000. Among the six antibiotics, the mechanisms of action of four have been reported ${ }^{5}$, while those of amphomycin and 3-amino-3-deoxy-D-glucose have not been known.

Amphomycin was found by Heinemann et al. ${ }^{6}$, and the structure was clarified by BodanszKy et al. ${ }^{7)}$ It is active against Gram-positive bacteria and consists of a fatty acid combined with eleven amino acids. The mechanism of action of amphomycin was studied by the authors as an extension of this screening program, and the primary site of action was found to be phospho-MurNAc-penta- 
peptide translocase in the lipid cycle in peptidoglycan synthesis ${ }^{8 \sim 10)}$.

3-Amino-3-deoxy-D-glucose, one of the constituents of kanamycin, was isolated in this screening program and was found to be an inhibitor of cell wall synthesis. In contrast kanamycin is a known inhibitor of protein synthesis. 3-Amino-3-deoxy-D-glucose was produced by Bacillus cereus var. SA1127 in our laboratory, but it had previously been isolated from Bacillus aminoglucosidicus ${ }^{11}$. The primary site of action of 3-amino-3-deoxy-D-glucose was found to be the formation of glucosamine6-phosphate from fructose-6-phosphate, a reaction catalyzed by glucosamine synthetase ${ }^{12,13}$.

Azureomycin, the new antibiotic discovered by this screening procedure, is a new cell wall inhibitor with a relatively low molecular weight. The taxonomy, isolation, properties and mode of action will be reported in the following papers ${ }^{14,15}$.

\section{Acknowledgements}

We wish to thank Mr. M. Shinohara, Mrs. N. Yamada, Mr. S. Shimizu, Miss K. Nishigaki, Miss H. HoNDA and Mr. H. IKEDA for their helpful assistances. Thanks are also due to our many colleagues with whom we have discussed this problem. This work was partially supported by a Grant-in-Aid for Scientific Research from The Ministry of Education, Science and Culture of Japan.

\section{References}

1) Arai, S.; K. Yoshida, A. Izawa, K. Kumagai \& N. Ishida: Effect of antibiotics on growth of Mycoplasma pneumoniae MaC. J. Antibiotics, Ser. A 19: 118 120, 1966

2) RaZIN, S.: Structure and function in Mycoplasma. Ann. Rev. Microb. 23: 317 356, 1969

3) Maniloff, J. \& H. J. Morowitz: Cell biology of the mycoplasma. Bacteriol. Rev. 36: 263 290, 1972

4) Buchanan, R. E. (Chairman): Bergey's Manual of Determinative Bacteriology. The Williams \& Wilkins Company, 8th Ed. Baltimore, 1974

5) Gale, E. F.; E. Cundliffe, P. E. Reynolds, M. H. Richmond \& M. J. Waring: The Molecular Basis of Antibiotic Action. John Wiley \& Sons, London, New York, Sydney, Tronto, 1972

6) Heinemann, B.; M. A. Kaplan, R. D. Muir \& I. R. Hooper: Amphomycin, a new antibiotic. Antibiot. \& Chemoth. 3: 1239 1242, 1953

7) Bodanszky, M.; G. F. Sigler \& A. Bodanszky: Structure of the peptide antibiotic amphomycin. J. Am. Chem. Soc. 95: 2352 2357, 1973

8) Ōmura, S.; H. Tanaka, M. Shinohara, R. Ōiwa \& T. Hata: Inhibition of bacterial cell wall synthesis by amphomycin. Chemotherapy (Proc. 9th Int. Cong. Chemoth.) 5: 365 369, 1975

9) Tanaka, H.; Y. Iwai, R. Ōima, S. Shinohara, S. Shimizu, T. OKa \& S. Ōmura: Studies on bacterial cell wall inhibitors. II. Inhibition of peptidoglycan synthesis in vivo and in vitro by amphomycin. Biochim. Biophys. Acta 497: 633 640, 1977

10) Tanaka, H.; R. Ōima, S. Matsukura \& S. Ōmura: Amphomycin inhibits phospho-N-acetylmuramylpentapeptide translocase in peptidoglycan synthesis of Bacillus. Biochem. Biophys. Res. Commun. 86: $902 \sim 908,1979$

11) Umezawa, S.; K. Umino, S. Shibahara, M. Hamada \& S. Omoto: Fermentation of 3-amino-3-deoxyD-glucose. J. Antibiotics 20: 355 360, 1967

12) Ifai, Y.; H. Tanaka, R. Ōiwa, S, Shimizu \& S. Ōmura: Studies on bacterial cell wall inhibitors. III. 3-Amino-3-deoxy-D-glucose, an inhibitor of bacterial cell wall synthesis. Biochim. Biophys. Acta 498: $223 \sim 228,1977$

13) Tanaka, H.; S. Shimizu, R. ŌIwa, Y. Iwai \& S. Ōmura: The site of inhibition of cell wall synthesis by 3-amino-3-deoxy-D-glucose in Staphylococcus aureus. J. Biochem. 86: 155 159, 1979

14) Ōmura, S.; H. Tanaka, Y. Tanaka, P. Spiri-Nakagawa, R. Ōima, Y. Takahashi, K. Matsuyama \& Y. IWAI: Studies on bacterial cell wall inhibitors. VII. Azureomycins A and B, new antibiotics produced by Pseudonocardia azurea, nov. sp. Taxonomy of the producing organism, isolation, characterization and biological properties. J. Antibiotics 32: 985 994, 1979

15) Spiri-Nakagawa, P.; Y. Tanaka, R. Ōiwa, H. Tanaka \& S. Ōmura: Studies on bacterial cell wall inhibitors. VIII. Mode of action of a new antibiotic, azureomycin B, in Bacillus cereus T. J. Antibiotics 32: $995 \sim 1001,1979$ 